\title{
Pengembangan Alat Seismograf Sederhana Sebagai Media Pembelajaran Materi IPS di SD
}

\author{
${ }^{1}$ Nur Alawiyah, ${ }^{2}$ Tuti Istianti, ${ }^{3}$ Muh. Husen Arifin \\ ${ }_{1,2,3}$ Universitas Pendidikan Indonesia \\ Kampus Cibiru, Jl. Pendidikan No.15, Cibiru Wetan, Cileunyi, Bandung, Jawa Barat 40625 \\ ${ }^{1}$ nuralwiyh@upi.edu \\ 2tutiistianti@upi.edu \\ ${ }^{3}$ muhusenarifin@upi.edu
}

\begin{abstract}
Learning media is one of the essential components in the world of education. In its use, learning media is used to explain and convey information related to the learning that is being carried out. Learning media helps teachers to be able to attract students' attention when learning. The cause of this is to take a look at the impact of using simple seismograph learning media on the impact of Indonesia's geographical location in elementary school. Social studies learning in this elementary school needs an update so that when delivering material it does not only use the lecture method which results in making students bored and not involved when learning. Therefore, researchers made this research so that teachers can always develop a renewal, namely by developing learning media in the form of a simple designed seismograph. The results of this study can be concluded by developing a simple seismograph tool as a learning medium for social studies material in elementary schools about the impact of Indonesia's geographical location on the sample material taken, namely earthquakes. It can be stated that in the use and manufacture of this simple seismograph tool, it is able to make students involved in learning, make students curious when studying and can motivate students to learn actively. Its simple construction is an added value in the development of this learning media because it is suitable for use for elementary school children.
\end{abstract}

Keywords: Learning Media, Seismograph Tools, Social Studies Material, Geographical Impact

\begin{abstract}
ABSTRAK
Media pembelajaran merupakan salah satu komponen penting dalam dunia pendidikan. Dalam penggunaannya media pembelajaran digunakan untuk menjelaskan serta menyampaikan informasi terkait pembelajaran yang sedang dilaksanakan. Media pembelajaran membantu guru untuk menarik perhatian siswa ketika belajar. Tujuan dari penelitian ini adalah untuk mengetahui pengaruh dari pengembangan media pembelajaran alat seismograf sederhana pada materi dampak letak geografis Indonesia di SD. Pembelajaran IPS di sekolah dasar ini perlu adanya suatu pembaharuan agar saat menyampaikan materi tidak dengan menggunakan metode ceramah saja yang hasilnya membuat siswa bosan dan tidak terlibat saat belajar. Oleh karena itu, peneliti membuat penelitian ini agar guru dapat selalu mengembangkan sebuah pembaharuan yaitu dengan mengembangkan media pembelajaran berbentuk alat seismograf yang dirancang sederhana. Penelitian ini menggunakan metode deskriptif. Hasil dari penelitian dapat disimpulkan bahwa dengan mengembangkan alat seismograf sederhana sebagai media pembelajaran pada materi IPS di SD tentang dampak letak geografis Indonesia pada sampel materi yang diambil yaitu gempa bumi. Dapat dinyatakan bahwa dalam penggunaan serta pembuatan alat seismograf sederhana ini mampu membuat siswa terlibat dalam pembelajaran, menjadikan rasa ingin tahu siswa tinggi saat belajar serta dapat memotivasi siswa belajar dengan aktif. Pembuatannya yang sederhana menjadi nilai tambah pada pengembangan media pembelajaran ini karena cocok digunakan untuk anak sekolah dasar.
\end{abstract}

Kata Kunci : Media Pembelajaran, Alat Seismograf, Materi IPS, Dampak Geografis

\section{PENDAHULUAN}

Media pembelajaran sebagai alat bantu belajar siswa saat di kelas. Media pembelajaran digunakan untuk dapat merangsang daya pikir, kemampuan serta menarik perhatian siswa saat belajar. Menurut Gerlach dan Ely : 1971 yang dikutip dalam penelitian Grabowski \& Branch [1] Media pembelajaran adalah berupa alat grafis, elektronis serta fotografis yang memiliki kegunaan untuk menyusun, menangkap, memproses informasi dalam bentuk visual dan verbal. [2] Media pembelajaran adalah sebuah aplikasi penyalur pesan dan informasi belajar mengajar. Sebuah media pembelajaran yang dirancang dengan baik akan dapat membantu siswa dalam mencapai tujuan pembelajaran. [3] Tidak hanya itu, media pembelajaran ini mampu meningkatkan hasil belajar siswa dengan difasilitasinya media pembelajaran diruang kelas mampu membuat proses belajar mengajar menjadi mudah dan praktis, meningkatnya 
konsentrasi belajar siswa karena adanya media yang menarik dan tentunya sesuai dengan kebutuhan siswa.

Media pembelajaran yang hendak digunakan oleh guru nantinya haruslah cocok dengan materi atau modul pelajaran yang hendak dipelajari. Pemakaian pada perlengkapan media pembelajaran dalam mata pelajaran IPS di SD diharapkan sanggup memudahkan siswa untuk menekuni materi IPS di SD dengan lingkungannya. Oleh sebab itu, media yang di informasikan kepada siswa haruslah menarik supaya bisa memotivasi siswa untuk belajar. Dengan terdapatnya penggunaan dan pengembangan pada perlengkapan media pembelajaran guru hendak lebih mudah untuk mengantarkan materi IPS di kelas. Selaku wujud usaha guru dalam memaksimalkan pembelajaran IPS di SD hingga butuh adanya pengembangan media pendidikan yang interaktif, kreatif dan menarik.

Pembelajaran IPS di sekolah dasar menurut Susanto : 2014 yang dikutip dalam penelitian [4] dibutuhkan adanya pembaharuan. Model pendidikan yang digunakan kala ini masih bertabiat konvensional. Pendidikan lebih kerap memakai tata cara ceramah. Buku bacaan teks merupakan salah satu sumber belajar yang harus dipahami oleh siswa. Pengajaran menggunakan tata cara ceramah membuat siswa kurang ikut serta dalam aktivitas kegiatan belajar di kelas. [5] Pembelajaran IPS di lapangan masih diajarkan dengan cara yang parsial dan dalam proses pembelajaran guru kurang mengembangkan kegiatan belajar yang menarik dan inovatif bagi siswa. [6] Seharusnya guru dituntut untuk memiliki ide dan wawasan yang luas dan kompetensi yang memadai agar dapat mewujudkan sebuah aspek pembaharuan dalam pembelajaran IPS di SD.

[7] Strategi yang dibuat untuk tingkatkan motivasi belajar siswa kerap menjadi permasalah tertentu untuk guru dikala ini. Guru wajib mempraktekkan strategi, prinsip dan cara untuk dapat memotivasi siswa untuk belajar mendesain dan merancang suatu pembelajaran. Pengembangan media pembelajaran di sekolah sebagai alat bantu guru dalam menyampaikan materi yang akan disampaikan merupakan komponen yang sangat penting. Guru harus selalu berinovasi merancang serta mengembangkan hal-hal baru agar kegiatan belajar mengajar tidak membosankan bagi siswa. Oleh sebab itu, tujuan dari riset ini dibuat untuk mengenali pengembangan dan efektifitas media pembelajaran yang digunakan dalam mata pelajaran IPS di SD. Dalam mengembangkan media pembelajaran alat pendeteksi gempa sederhana (seismograf) pada materi tentang dampak dari letak geografis Indonesia di SD kelas tinggi. Dengan mengembangkan alat pendeteksi gempa sederhana tersebut diharapkan siswa mampu mengetahui dampak-dampak dari pengaruh letak geografis di Indonesia. Pengaruh dari letak geografis di Indonesia salah satunya ialah rawan terjadi bencana alam seperti gunung meletus, banjir dan gempa bumi. Gempa bumi merupakan salah satu sampel yang akan diambil dalam penelitian ini untuk mengembangkan media pembelajaran alat seismograf sederhana di SD kelas tinggi.

\section{KAJIAN PUSTAKA \\ Alat Peraga}

Perlengkapan alat peraga atau disebut media pembelajaran ini. Dijadikan sebagai peranan yang paling penting. Apalagi dalam memastikan keberhasilan proses pendidikan itu sendiri. Hingga media pendidikan dalam totalitas sistem area belajar wajib memperoleh atensi dari guru [8] Di era globalisasi ini seluruh aktivitas dapat digunakan secara praktis dan sederhana dengan adanya alat teknologi yang canggih. Sama seperti halnya dalam mengembangkan alat media pembelajaran guru dituntut untuk dapat mencari berbagai rancangan baru. Dikutip dari artikel [8] menurut Mujiono (1994 : 31) dalam tahap belajar mengajar terdapat 4 komponen yang berarti sangat mempengaruhi untuk keberhasilan belajar siswa, salah satunya ialah bahan ajar, suasana belajar, media serta sumber belajar dan guru 
selaku subyek pendidikan. Komponen-komponen tersebut memiliki peran yang berarti bagi sangat berarti dalam proses belajar mengajar. Sehingga melemahnya satu atau lebih komponen yang bisa membatasi tercapainya tujuan belajar yang optimal.

\section{Pembelajaran IPS}

Pada mata pelajaran IPS di SD media atau alat pembelajaran jadi salah satu komponen utama sebagai keberhasilan belajar IPS di SD. Media pembelajaran yang disampaikan tentunya haruslah jelas dan dapat dipahami dengan mudah oleh siswa. Oleh karena itu, peneliti ingin membuat sebuah penelitian terkait keefektifan media pembelajaran pada mata pelajaran IPS di SD dengan cara mengembangkan media pembelajaran alat seismograf sederhana pada materi pembelajaran IPS di SD tentang dampak letak geografis Indonesia.

\section{Seismograf}

Seismograf adalah sebuah perangkat untuk mengukur dan mencatat adanya guncangan dari gempa bumi. [9] Gempa bumi adalah suatu fenomena alam yang terjadi adanya pergeseran antara lempeng pada permukaan bumi. Gempa bumi ini bersifat destruktif, yang artinya setiap kejadian hampir memberikan kerugian dalam hal apapun di kehidupan manusia. Kini, alat seismograf dapat dibuat secara sederhana. Bahan-bahan yang digunakan pun sangat dapat dicari di lingkungan rumah. Salah satu bahan utamanya adalah menggunakan plastisin. Pembuatan alat seismograf sederhana ini dapat dipraktekkan oleh anak-anak di sekolah sebagai bahan ajar pada materi pelajaran IPS di SD. Selain itu, manfaat dari pembuatan alat seismograf sederhana ini dapat membuat anak-anak berkarya serta berimajinasi karena dalam pembuatannya yang mudah serta bahan dan alat yang dapat dicari di sekitar rumah. Melalui alat seismograf sederhana ini anak-anak diarahkan agar dapat memahami cara kerja sebuah alat pendeteksi getaran yang berasal dari dalam bumi yaitu gempa bumi. Tidak hanya itu, pembuatan alat seismograf sederhana dalam penggunaannya mampu bermanfaat untuk melatih motorik, mengembangkan kreativitas siswa, daya pikir dan rasa ingin tahu siswa terhadap materi yang sedang diajarkan saat penggunaan alat tersebut digunakan. Bahan-bahan yang digunakan untuk membuat alat seismograf sederhana ini sangatlah mudah di dapat dan di gantikan dengan yang lebih sederhana jika ada bahan yang tidak tersedia di rumah. Berikut adalah bahan-bahan yang dapat digunakan untuk pembuatan alat seismograf sederhana yaitu :

1. Plastisin

2. Botol bekas/ kardus bekas

3. Pulpen atau spidol.

4. Benang

5. Kertas

Cara pembuatannya pun sederhana : 1). mula-mula siapkan botol bekas maupun kardus yang akan dijadikan tempat penggantung pulpen. Anak-anak dapat berkreasi mengembangkan kreativitasnya untuk memilih bahan yang akan digunakan. 2). Lalu siapkan plastisin, bentuklah menjadi bulat dan terapkan pada pulpen yang telah disediakan. 3). Terapkan plastisin sampai ujung pulpen sehingga titik pulpen terasa berat. 4). Siapkan benang, ikatkan pada pulpen yang telah diberi plastisin. 5). Lalu masukan ke dalam tempat yang akan dibuat sebagai penggantung. Jika anak-anak memilih untuk menggunakan kardus maka buatlah lubang di atas kardus dan memasukan pulpen ke dalam kardus, ikat benang ke atas lubang kardus. Jika, anakanak memilih untuk menggunakan botol bekas, maka langkah pertama dalam memasukan pulpen ke dalam botol adalah dengan memotong bagian bawah botol dan membuat lubang pada tutup botol. 6). Selanjutnya ikatkan benang pada pulpen ke dalam tutup botol yang telah di beri lubang lalu masukan ke dalam botol dan tutup hingga rapat. Terakhir, simpan kertas kosong di bawah pulpen. Alat seismograf sederhana sudah dapat digunakan.

[10] Produk pendidikan yang baik adalah memikirkan bagaimana dapat menciptakan sebuah alat pendeteksi gempa agar bisa dimiliki oleh masing-masing di rumah, walau hanya 
alat pendeteksi yang sederhana namun diharapkan mampu membantu deteksi bencana yang akan datang nanti.

Berdasarkan uraian diatas mengenai cara pembuatan alat seismograf sederhana terbilang cukup mudah untuk dipraktekkan anak-anak, dengan alat dan bahan yang dapat dicari di dalam rumah. Melihat pada pembuatannya, anak-anak dapat memilih berdasarkan kreativitasnya sendiri untuk menggunakan bahan apa yang akan digunakan sebagai tempat penggantung pada seismograf. Dari langkah tersebut dapat dikatakan bahwa dengan mengajak siswa membuat media pembelajaran sederhana mampu mengembangkan kreativitas siswa

\section{HASIL DAN PEMBAHASAN}

Dikutip dari skripsi penelitian oleh Resasmita [11] mengatakan jika menggunakan permainan di sela-sela waktu aktivitas belajar, bisa tingkatkan kreatifitas dalam mengeksplorasi ide-ide. Riset ini meyakinkan jika dengan memakai permainan plastisin bisa meningkatkan serta sangat sesuai untuk anak sekolah. Implikasi dari riset ini meliputi campur tangan pihak sekolah, dan diharapkan bisa membagikan sarana yang lebih, lengkap, peserta didik untuk di sela-sela waktu aktivitas belajar yang diselingi oleh metode bermain. Sehingga anak dapat mengekspresikan ide-ide secara imaginatif.

Adapun hasil penelitian dari Apriyanto [12] dikarenakan sekolah belum mempunyai perlengkapan peringatan gempa yang diperlukan. Oleh sebab itu, aktivitas ini diharapkan bisa tingkatkan keahlian peserta didik dalam membuat perlengkapan alat peringatan dini yang sederhana. Serta sudah teruji aktivitas ini bisa tingkatkan pengetahuan guru-guru di SD N 2 serta 3 Merak Belantung mengenai adanya gempa bumi serta dampaknya. Aktivitas ini pun dapat tingkatkan keahlian guru-guru untuk membuat alat perlengkapan peringatan dini gempa bumi dengan sederhana.

Hasil dari penelitian Hasna Mudzakiroh [13] membuktikan dari penggunaan alat peraga yaitu alarm gempa bumi dapat dikatakan akurat dan memenuhi prinsip relevansi dalam pemakaian media pembelajaran dengan hasil persentase yang didapatkan adalah senilai 93.05\%. Dan presentasi belajar siswa sesudah ikuti pembelajaran dengan memakai alat pendeteksi gempa sederhana yang sudah dikembangkan dan dijadikan sebagai bahan ajar memiliki nilai keakuratan $90.00 \%$. Perihal ini membuktikan bahwa dalam penggunaan alat pendeteksi gempa sederhana tersebut sudah dapat dikatakan memenuhi prinsip daya guna, efisiensi serta produktivitas.

Hasil penelitian dari skripsi Alfi Syahri [14] Produk yang dibuat sebagai alarm gempa bumi ini dengan pematerian yang diambil dari modul listrik dinamis, media pembelajaran ini diharapkan mampu menunjang pembelajaran peserta didik yang mempelajari materi tentang listrik dinamis dan telah dilengkapi oleh beberapa komponen serta contoh yang berikatan dengan kehidupan sehari-hari dan dapat membuat peserta didik untuk belajar secara mandiri.

Berdasarkan beberapa penelitian diatas jika disimpulkan dapat berbagai hasil yang telah peneliti bandingkan. Yang pertama, alat peraga berupa seismograf sederhana dapat dikatakan menjadi alat media pembelajaran yang efektif untuk bahan ajar siswa di kelas menyesuaikan dengan materi yang berkaitan dengan alat tersebut juga. Yang kedua, dalam pembuatan alat seismograf ini mampu meningkatkan kreativitas siswa dalam berkreasi dan berkarya untuk membuat alat tersebut. Ketiga, dengan menggunakan alat seismograf sederhana sebagai media pembelajaran pada materi pelajaran yang akan dipelajari akan membantu siswa untuk memotivasi belajar, membuat tinggi rasa ingin tahu dan memberikan kesadaran bagi siswa terkait adanya gempa bumi. [15] Dengan adanya alat pendeteksi gempa bumi, setidaknya dapat mengantisipasi adanya gempa bumi, dalam hal ini dapat dinyatakan bahwa alat pendeteksi gempa diperlukan baik digunakan oleh daerah yang rawan gempa bumi maupun tidak. 
Oleh karena itu, peneliti membuat sebuah penelitian ini dengan cara meneliti pengembangan alat seismograf sederhana pada materi IPS di SD tentang dampak letak geografis. Jika dihubungkan dengan hasil penelitian oleh Maulana Alfisyahri : 2018. Pada materi dampak dari letak geografis Indonesia pun dapat dikatakan efektif jika mengembangkan alat seismograf sederhana sebagai media pembelajaran di SD kelas tinggi.

Sampel materi yang akan disampaikan adalah tentang dampak letak geografis Indonesia. Materi ini sangat berkaitan dengan media pembelajaran dari alat seismograf sederhana. Salah satu materi yang diuji adalah sering terjadinya gempa bumi akibat pengaruh letak geografis Indonesia. Sebab Indonesia terletak pada 3 lempeng utama dunia adalah lempeng Pasifik, lempeng Eurasia serta lempeng Australia. Gempa bumi terjadi akibat adanya tumbukan dari antar lempeng utama. Oleh karena itu sebagian besar wilayah di Indonesia rawan terjadi gempa bumi. Dengan adanya pengembangan media pembelajaran berupa alat seismograf sederhana ini, diharapkan siswa mampu mengetahui dampak dari letak geografis Indonesia. Pembuatannya pun tidak terlalu sulit untuk dibuat oleh anak-anak. Alat dan bahan sederhana dapat dicari di sekeliling rumah, bahan utamanya adalah plastisin. Plastisin dalam hasil penelitian oleh Resasmita : 2017 dapat meningkatkan kreativitas anak dan lebih cocok untuk digunakan pada anak-anak.

Hasil dari penelitian ini dapat dikatakan bahwa pengembangan media pembelajaran alat seismograf sederhana dapat berjalan efektif baik pada anak-anak sampai orang dewasa. Jika dilihat dari cara pembuatannya sangat cocok untuk anak-anak yaitu mudah dan praktis. Penggunaan alat ini juga sangat sesuai dengan materi yang sedang diteliti ini yaitu tentang pengaruh dampak letak geografis Indonesia setelah dibandingkan oleh hasil para peneliti di atas. Karena dengan membuat alat pendeteksi gempa sederhana dapat membuat siswa aktif belajar serta membuat rasa ingin tahunya tinggi terhadap materi yang sedang dipelajari. Siswa lebih senang menggunakan media belajar yang lebih nyata dan ada objeknya. Maka dari itu, pengembangan alat seismograf sederhana ini dinyatakan dapat membantu mengefektifkan kegiatan belajar siswa pada materi IPS tentang dampak geografis Indonesia di SD kelas tinggi.

\section{KESIMPULAN DAN SARAN}

Penelitian ini dilakukan untuk mengetahui pengembangan media pembelajaran seismograf sederhana di sekolah dasar pada materi IPS tentang dampak letak geografis di Indonesia. Media pembelajaran memiliki peran yang penting untuk proses kegiatan belajar mengajar di kelas. Manfaat dengan adanya media pembelajaran di sekolah diharapkan dapat membantu siswa dan guru dalam melaksanakan kegiatan belajar secara nyata objek yang sedang dipelajari. Untuk meneliti keefektifan media pembelajaran seismograf sederhana ini peneliti mencari beberapa dari hasil penelitian yang telah di uji coba dari keempat artikel penelitian yang dijadikan sebagai data penelitian. Dari keempat penelitian tersebut dapat disimpulkan bahwa pengembangan media pembelajaran alat seismograf dapat berjalan efektif pada materi pelajaran yang sesuai dengan tujuan alat tersebut digunakan, maka dapat dikatakan dalam penggunaanya pada materi tentang dampak letak geografis di Indonesia ini yang sedang diuji oleh peneliti, hasilnya akan sama akurat seperti hasil dari penelitian yang dilakukan oleh Alfiansyah dalam artikelnya dengan materi ajar tentang listrik dinamis. Lalu pembuatan alat seismograf sederhana ini pun sudah dibuktikan dapat dibuat dengan mudah dan praktis dengan didukung oleh bahan-bahan yang mudah dicari dan aman sehingga cocok untuk siswa SD. Tidak hanya itu penggunaan melalui media pembelajaran alat seismograf ini dinyatakan dapat menjadikan siswa termotivasi saat belajar serta menarik rasa ingin tahu siswa. Oleh karena itu, dengan dilakukannya pengembangan pada media pembelajaran alat seismograf sederhana diharapkan mampu membuat kesadaran kepada guruguru betapa pentingnya untuk mengembangkan sebuah media pembelajaran agar media yang digunakan tersebut tidak hanya seperti itu-itu saja akan tetapi dibuat perubahan baru yang perlu dilakukan baik dalam perancangan pembuatannya maupun manfaatnya bagi siswa di kelas.

Untuk dapat meningkatkan motivasi, keaktifan dan rasa ingin tahu siswa yang tinggi saat pembelajaran materi IPS di SD tentang dampak letak geografis di Indonesia. Guru sebaiknya perlu mengembangkan sebuah media pembelajaran yang sifatnya nyata, salah contohnya satunya adalah 
dengan mengembangkan alat seismograf sederhana pada materi dampak letak geografis Indonesia sampel materi yang digunakan tentunya adalah mengenai gempa bumi. Alat seismograf tersebut dijadikan bahan media pembelajaran sehingga siswa dapat secara langsung melakukan uji coba praktik mendeteksi gempa bumi dan disertai guru memberikan penguatan edukasi mengenai gempa bumi.

\section{DAFTAR PUSTAKA}

[1] S. Grabowski and R. Branch, "Teaching \& Media: A Systematic Approach," Retrieved, August, vol. 14, p. 2018, 2003.

[2] T. Nurseto, "Membuat Media Pembelajaran yang Menarik," J. Ekon. dan Pendidik., vol. 8, no. 1, pp. 19-35, 2012, doi: 10.21831/jep.v8i1.706.

[3] N. M. Dwijayani, "Development of circle learning media to improve student learning outcomes,” J. Phys. Conf. Ser., vol. 1321, no. 2, pp. 171-187, 2019, doi: 10.1088/1742-6596/1321/2/022099.

[4] A. H. Sumitro, P. Setyosari, and Sumarmi, "Penerapan Model Problem Based Learning meningkatkan Motivasi dan Hasil Belajar IPS," J. PendidikanTeori, Penelitian, dan Pengemb., vol. 2, no. 9, pp. 1188-1195, 2017, [Online]. Available: http://journal.um.ac.id/index.php/jptpp/article/view/9936/4696.

[5] D. T. Suarno and S. Sukirno, "Pengembangan Media Pembelajaran Ips Dengan Tema Pemanfaatan Dan Pelestarian Sungai Untuk Siswa Kelas Vii Smp,” Harmon. Sos. J. Pendidik. IPS, vol. 2, no. 2, pp. 115-125, 2015, doi: 10.21831/hsjpi.v2i2.7663.

[6] S. I. Astuti, S. P. Arso, and P. A. Wigati, 済無No Title No Title No Title, vol. 3. 2015.

[7] T. Tumini, "Peningkatan Motivasi dan Prestasi Belajar dengan Multimedia pada Pembelajaran IPS di Sekolah Dasar," GulawentahJurnal Stud. Sos., vol. 4, no. 2, p. 93, 2019, doi: 10.25273/gulawentah.v4i2.5556.

[8] Wenny Krissantono, "Pemanfaatan Media Pembelajaran Meningkatkan Motivasi Belajar Ilmu Pengetahuan Alam Kelas Vi Sdn 03 Kelampai,” p. 1, 2013.

[9] B. Usmanto and B. H.S.U, "Rancang Bangun Alat Pengukur Gempa Berbasis Internet Of Things (IoT)," Pros. Semin. Nas. Darmajaya, vol. 1, no. 0, pp. 264-270, 2019, [Online]. Available: https://jurnal.darmajaya.ac.id/index.php/PSND/article/view/1725.

[10] A. Andriani, "Bandul si Alarm Gempa Produk Implementasi STEAM dalam Pembelajaran Fisika Berbasis Inquiry Pada kelas XI MIA 4 di SMAN 4 Kejuruan Muda Tp 2019/2020," GRAVITASI J. Pendidik. Fis. dan Sains, vol. 3, no. 01, pp. 611, 2020, doi: 10.33059/gravitasi.jpfs.v3i01.2312.

[11] I. T. D. Urgència, “No 主観的健康感を中心とした在宅高齢者における 健康関連 指標に関する共分散構造分析Title,”pp. 1-23, 2017.

[12] D. K. Apriyanto, A. Surtono, G. A. Pauzi, H. R. Ayu, S. Anwar, and G. S. Siregar, "Pembinaan Pembuatan Alat Deteksi Dini Gempa Bumi Sederhana Dan Trauma Healing Di Sd N 3 Merak Belantung Lampung Selatan,” vol. 8347, 2020, [Online]. Available: https://ejournal.amikompurwokerto.ac.id/index.php/jpmm/article/view/1132/pdf_44.

[13] P. Materi et al., "PENGEMBANGAN ALAT PERAGA ALARM GEMPA BUMI SEBAGAI MEDIA Hasna Mudzakiroh , Eko Hariyono,” vol. 02, no. 03, pp. 11-18, 2013. 
p-ISSN : 2655-7304

e-ISSN : 6655-8953

[14] M. Alfisyahri, "Pengembangan Alarm Gempa Bumi Sebagai Media Pembelajaran Fisika SMA Kelas XII Materi Listrik Dinamis,” 2019, [Online]. Available: http://repository.radenintan.ac.id/5721/1/skripsi.pdf.

[15] N. I. F. - AMIK BSI Purwokerto and A. A. - AMIK BSI Purwokerto, "Pembuatan Alat Pendeteksi Gempa Menggunakan Accelerometer Berbasis Arduino," Evolusi J. Sains dan Manaj., vol. 6, no. 1, pp. 61-67, 2018, doi: 10.31294/evolusi.v6i1.3582. 